\title{
AKTUALISASI NILAI-NILAI OLAHRAGA SEBAGAI UPAYA MEMBANGUN KARAKTER BANGSA
}

\author{
Yustinus Sukarmin \\ FIK Universitas Negeri Yogyakarta (e-mail: yustinussukarmin@yahoo.com; \\ HP: 08122722649)
}

\begin{abstract}
Actualization of Sports Values as an Attempt to Build Nation Character. Honesty, caring, politeness, loyalty, discipline, and responsibility are some good values that should be the foundations the nation's life. At present, however, they are rarely found in daily life. Deceit, carelessness, rudeness, hypocrisy, and negligence are more dominant in the country. In sports, some good values, such as devotion, fairness, discipline, cooperation, and hard work can be actualized as an attempt to rebuild the nation character. They must be actualized in various aspects of life through leaders' exemplary deeds in the family, school, society, and country.
\end{abstract}

Keywords: actualization, sports, character

\section{PENDAHULUAN}

Sejak dahulu kala, bangsa Indonesia dikenalsebagaibangsa yang ramah, santun, toleran, dan cinta damai. Namun, kini semua itu seolah telah berubah dan tinggal wacana. Bangsa Indonesia berubah menjadi bangsa yang pemarah, suka melakukan kekerasan, dan tidak lagi mengindahkan peraturan. Dengan kata lain, bangsa Indonesia telah kehilangan jati diri sebagai bangsa yang berbudaya dan berkarakter mulia. Menurut Capra (1998:3), Zohar dan Marshall (2000:16), krisis moral telah melanda bangsa ini, suatu kenyataan yang tidak pernah terbayangkan sebelumnya dan pantas menjadi keprihatinan bersama dari seluruh elemen bangsa ini

Dari berbagai bidang kehidupan, diperoleh bukti tentang hal tersebut, baik dalam skala kecil, seperti tindak kekerasan dalam keluarga yang menyebabkan penderitaan, bahkan kematian, maupun dalam skala besar, seperti penyerangan terhadap kelompok warga tertentu oleh kelompok warga lainnya yang berakibat pada terjadinya kerusakan fisik dan hilangnya nyawa. Dalam bidang pendidikan, perilaku tidak terpuji dari pelajar dan mahasiswa terus saja terjadi, seperti tawuran, kasus narkoba, dan perkosaan. "Perang" antarsuporter sepak bola yang terjadi dalam setiap pertandingan sepak bola yang menimbulkan korban jiwa dan kerugian harta benda sudah mencapai titik yang sangat merisaukan masyarakat.

Ketika kondisi masyarakat sudah demikian mengkhawatirkan, menurut Maksum (2009:25), banyak orang berpendapat agar pendidikan budi pekerti diajarkan kembali di sekolah. Para pakar mengusulkan seperti itu dengan berpijak pada pengalaman masa lampau bahwa pendidikan budi pekerti yang diajarkan dapat menuntun siswa 
ke jalan kehidupan yang mulia dan bermartabat. Pendapat ini seakan-akan memperkuat tuduhan para pakar bahwa anak-anak sekarang berperi-laku buruk karena tidak mendapatkan pendidikan budi pekerti. Benarkah perilaku buruk anak-anak sekarang akibat tidak mendapatkan pendidikan budi pekerti? Kalau hal itu benar, apakah pendidikan budi pekerti dapat meningkatkan akhlak anak-anak?

Suatu pertanyaan yang tidak mudah untuk dijawab. Diperlukan buktibukti yang akurat dan lengkap dalam suatu penelitian yang mendalam dan memerlukan waktu yang lama untuk menjelaskan masalah tersebut. Belum lagi yang terkait dengan masalah teknis pelaksanaan karena pendidikan budi pekerti bukan hanya sekedar transfer of knowledge kepada peserta didik, tetapi lebih kepada transfer of values. Apa artinya anak dapat menyebutkan berpuluhpuluh, bahkan ratusan nilai akhlak mulia yang ada, jika perilakunya menyimpang jauh dari yang diucapkan. Salah satu ciri manusia yang berkarakter ditunjukkan oleh satunya kata dengan perbuatan. Menurut Sudrajad (2010:1), karakter merupakan nilai-nilai perilaku manusia yang berhubungan dengan Tuhan YME, diri sendiri, sesama manusia, lingkungan, dan kebangsaan terwujud dalam pikiran, sikap, perasaan, perkataan, dan perbuatan berdasarkan norma-norma agama, hukum, tata kra$m a$, budaya, dan adat-istiadat. Suyanto (2010:1) mengatakan bahwa individu yang berkarakter baik adalah individu yang bisa membuat keputusan dan siap mempertanggungjawabkan setiap akibat dari keputusan yang dibuatnya.
Menurut Mutohir (2004:24), dalam kehidupan bangsa yang karut-marut ini, masih ada pihak-pihak yang tetap optimis dan menaruh harapan pada olahraga, meskipun disadari pula bahwa olahraga tidak dengan serta merta mampu mengatasi semua persoalan. Situasi dan gejolak sosial harus dihadapi dan disikapi dengan optimis untuk bisa mengubahnya kembali ke arah yang lebih baik. Kretchmar (2005: 191) menguatkan optimisme tersebut karena masyarakat dunia pada umumnya menjunjung tinggi delapan nilai utama dalam kehidupan manusia, yaitu: cinta kasih, kebenaran, keadilan, kemerdekaan, persatuan, toleransi, tanggung jawab, dan menghargai kehidupan. Walaupun demikian, menurut Maksum (2009:26), melalui olahraga orang dapat belajar banyak hal tentang nilai-nilai keutamaan hidup, seperti nilai persamaan dan kebersamaan, fair play, kedisiplinan, tanggung jawab, dan perjuangan. Timbul suatu pertanyaan baru, bagaimana implementasi aktualisasi nilainilai olahraga dalam kehidupan sehingga setiap warga negara Indonesia mampu mengintegrasikan dan menginternalisasikan nilai-nilai tersebut dalam hidupnya? Sebelum menguraikan hal tersebut, akan dijelaskan terlebih dahulu tentang konsep olahraga dan nilai-nilai olahraga, dan diakhiri dengan implementasi aktualisasi nilai-nilai olahraga.

\section{KONSEP OLAHRAGA}

Terdapat banyak batasan tentang olahraga yang disusun oleh para pakar, namun dalam tulisan ini, hanya akan disajikan beberapa batasan yang dipandang relevan dengan permasalahan. 
Menurut Undang-Undang Nomor 3 Tahun 2005, tentang Sistem Keolahragaan Nasional (UU RI No. 3 Th. 2005), Bab I, Pasal 1, ayat 4, olahraga adalah segala kegiatan yang sistematis untuk mendorong, membina, serta mengembangkan potensi jasmani, rohani, dan sosial. Berdasarkan tujuannya, olah-raga dibedakan menjadi tiga macam, yaitu: (1) olahraga pendidikan; (2) olahraga rekreasi; dan (3) olahraga prestasi. Di samping itu, menurut dasar pelaksanaannya, olahraga dibedakan menjadi tiga macam, yaitu: (1) olahraga amatir; (2) olahraga profesional; dan (3) olahraga penyandang cacat.

Semua macam olahraga yang telah disebutkan di atas mempunyai fungsi yang sama, yaitu mengembangkan jasmani, rohani, dan sosial serta membentuk watak dan kepribadian bangsa yang bermartabat (Bab II, Pasal 3). Wilkerson dan Dodder (1979:50) merinci tujuh fungsi olahraga, yaitu: (1) pelepasan emosi; (2) menunjukkan identitas; (3) kontrol sosial; (4) sosialisasi; (5) agen perubahan; (6) semangat kolektif; dan (7) sukses. Tujuan yang ingin dicapai melalui aktivitas olahraga, dapat dikelompokkan menjadi lima, yaitu: (1) memelihara dan meningkatkan kesehatan dan kebugaran, prestasi, kualitas manusia; (2) menanamkan nilai moral dan akhlak mulia, sportivitas, dan disiplin; (3) mempererat dan membina persatuan dan kesatuan bangsa; (4) memperkukuh ketahanan nasional; dan (5) mengangkat harkat, martabat, dan kehormatan bangsa (Bab II, Pasal 4).

Coakley (1978:12) mendefinisikan olahraga sebagai,
“... institutionalized competitive activity that involves vigorous physical exertion or the use of relatively complex physical skill, by individuals whose participation is motivated by combination of the intrinsic satisfaction associated with the activity itself and the external rewards earned through participation."

Batasan yang disampaikan oleh Coakley ini lebih menekankan pada aktivitas olahraga kompetitif yang terorganisasi.

Menurut Declaration of Sport yang diterbitkan oleh International Council of Sport and Physical Education (1972:10), olahraga adalah setiap kegiatan fisik yang mengandung sifat permainan dan berisi perjuangan dengan diri sendiri atau dengan orang lain atau konfrontasi dengan unsur-unsur alam. Kalau kegiatan ini meliputi juga pertandingan, kegiatan itu harus dilaksanakan dengan semangat điwa sportif. Tidak mungkin ada olahraga dalam arti yang sebenarnya tanpa fair play. Olahraga seperti itu merupakan alat pendidikan yang ampuh. Malim (1997:99) menekankan pentingnya fair play dalam olahraga, terutama yang bersifat prestasi, sebagai alat untuk mencegah terjadinya konflik di antara regu yang bertanding. Di dalam pertandingan olahraga, setiap regu yang bertanding sama-sama ingin meraih sasaran eksklusif, yaitu kemenangan atau kejayaan. Hal inilah yang dapat menjadi pemicu terjadinya konflik. Sisi positif atau kelebihan kegiatan olahraga dan positivisme seperti inilah yang dapat diajarkan kepada anak-anak muda melalui partisipasi dalam segala bentuk olahraga. 


\section{NILAI-NILAI OLAHRAGA}

Mutohir (2004:25) mengatakan bahwa olahraga pada hakikatnya adalah 'miniatur' kehidupan. Pernyataan ini mengandung maksud bahwa esensiesensi dasar dari kehidupan manusia dalam keseharian dapat dijumpai pula dalam olahraga. Contoh konkret yang dapat dikemukan di sini, misalnya persaingan. Dalam sepanjang kehidupannya, manusia tidak pernah luput dari persaingan, seakan-akan orang ditakdirkan untuk saling bersaing menjadi yang terbaik. Persaingan sudah dimulai sejak proses terjadinya manusia, yaitu ketika jutaan sel sperma saling bersaing untuk membuahi sel telur dengan beradu cepat dan kuat. Esensi persaingan itu akan terus berlanjut, yaitu ketika orang mencari sekolah, mendapatkan pekerjaan, meraih jabatan, dan sebagainya sampai menghembuskan napas yang terakhir.

Beberapa hal yang perlu mendapatkan perhatian serius dalam persaingan adalah agar persaingan tersebut dilakukan secara fair, mematuhi peraturan yang ada, menjunjung tinggi nilai moral dan keadilan. Dalam tulisan ini, disajikan contoh-contoh klasik dalam dunia olahraga yang menggambarkan keluhuran nilai yang tersimpan dalam kompetisi olahraga. Dalam olimpiade musim dingin di Austria, pada tahun 1964, Eugenio Monti, seorang atlet kereta luncur (bobsled) menunjukkan sebagai seorang kompetitor sejati. Setelah menyelesaikan luncuran dengan catatan waktu yang menakjubkan, ia menghampiri lawannya, Tony Nash, untuk meminjamkan salah satu komponen kereta luncur kepadanya. Monti mengetahui bahwa salah satu komponen kereta luncur Nash rusak, sehingga dikhawatirkan kereta itu tidak dapat melakukan luncuran. Ia berpeluang besar akan memenangi perlombaan dengan rusaknya kereta luncur Nash. Akhirnya, dengan bantuan onderdil Monti, kereta Nash dapat meluncur dengan sempurna, bahkan menciptakan rekor dunia dan mendapat medali emas.

Andaikata, Monti hanya berorientasi pada kemenangan, dapat dipastikan ia tidak akan meminjamkan onderdil tersebut kepada Nash dan ia sadar betul risikonya. Atlet dari Italia tersebut mempunyai pendirian bahwa tidak ingin menang di atas ketidakberdayaan lawan dan lebih memilih memberikan kesempatan yang sama kepada lawannya. Ia tidak menginginkan kemenangan yang "murahan". Perbuatan Monti tersebut jelas menunjukkan kepada dunia bahwa betapa pun orang bersaing, berkompetisi, hendaknya semua harus dilakukan secara fair. Oleh sebab itu, tidak mengherankan apabila kemudian Montidianugerahi International Fair Play untuk pertama kalinya (Mutohir, 2004: 26).

Kasus yang kedua berikut ini tidak kalah nilai moralitasnya dengan kasus yang pertama. Peristiwa ini terjadi pada tanggal 2 November 1969 dalam suatu pertandingan sepak bola babak final Liga Spanyol, Real Madrid versus Sabadell. Pedro Zaballa, pemain sayap kanan kesebelasan Sabadell yang tidak mau menendang (memasukkan) bola ke gawang lawan karena pada saat yang bersamaan penjaga gawang lawan (Real Madrid) mengalami cedera berat dan pingsan setelah bertabrakan dengan 
seorang back temannya. Setelah pertandingan selesai dengan kemenangan Real Madrid 1-0, penonton memberikan sorak penghormatan kepada Zaballa dengan standing ovation. Zaballa menyatakan bahwa ia hanya menuruti kata hatinya untuk tidak membuat gol dalam ketidakberdayaan lawan. Berkat tindakannya yang mulia itu, Zaballa dianugerahi International Fair Play (Mutohir, 2004:27).

Di tengah karut-marutnya kehidupan masyarakat dewasa ini, ketika orang saling berebut kekuasaan, jabatan, pengaruh, dan lainnya dengan menghalalkan segala cara, kehadiran Monti dan Zaballa sangat dibutuhkan. Dalam suasana seperti sekarang ini, sangat dibutuhkan orang-orang yang tidak haus kekuasaan dengan menghalalkan segala cara untuk meraih kemenangan; sangat dibutuhkan orang-orang yang dalam setiap sepak terjangnya menjunjung tinggi nilai-nilai moral kemanusiaan. Untuk mewujudkan semuaitu, diperlukan individu-individu yang berkarakter dan memegang teguh nilai-nilai kebangsaan. Menurut Mutohir (2004:27), dalam konteks inilah, olahraga menjadi bagian penting sebagai sebuah instrumen pembentukan nilai dan karakter kebangsaan.

Olahraga mengajarkan kedisiplinan, jiwa sportif, tidak mudah menyerah, jiwa kompetitif yang tinggi, semangat bekerja sama, mengerti akan aturan, berani mengambil keputusan kepada seseorang. Menurut Mutohir (2004:28), hal ini relevan dengan pemikiran Baron Pierre de Coubertin, Bapak Olimpiade Modern, bahwa tujuan olahraga terletak pada fungsinya, yaitu:
"As the unique school of moral perfection, and as the means for the acquisition and formation of strong personality, good character and noble sentimens; only men with these moral virtues can be useful member of society."

Citius, altius, dan fortius adalah motto atau semboyan Olympic Movement yang membawa manusia menuju kepada kesempurnaan hidup. Citius, sesungguhnya tidak hanya dimaknai sebagai lebih cepat atau tercepat seperti yang ditunjukkan oleh seorang atlet lari. Sejatinya, citius menunjukkan kualitas mental seseorang yang mampu mengambil keputusan dengan lebih cepat dan lebih cerdas. Makna altius, bukan hanya lebih tinggi atau tertinggi mencapai prestasi, misalnya lompat tinggi atau lompat galah dalam atletik, namun menunjuk pada moral yang lebih luhur dan mulia. Fortius, sejatinya tidak hanya berarti lebih kuat atau terkuat dalam prestasi angkat besi atau angkat berat, tetapi menunjuk pada kualitas pribadi yang lebih ulet dan tangguh.

United Nations (Maksum, 2009:27) menyatakan bahwa olahraga merupakan instrumen yang efektif untuk mendidik kaum muda, terutama dalam nilai-nilai. Sejumlah nilai yang ada dan dapat dipelajari melalui aktivitas olahraga meliputi: cooperation, communication, respect for the rules, problem-solving, understanding, connection with others, leadership, respect for others, value of effort, how to win, how to lose, how to manage competition, fair play, sharing, self-esteem, trust, honesty, self-respect, tolerance, resilience, team-work, disciline, dan confidence. 
Gambar di bawah ini akan menjelaskan bagaimana olahraga dapat men- jadi instrumen pembentukan nilai dan karakter.

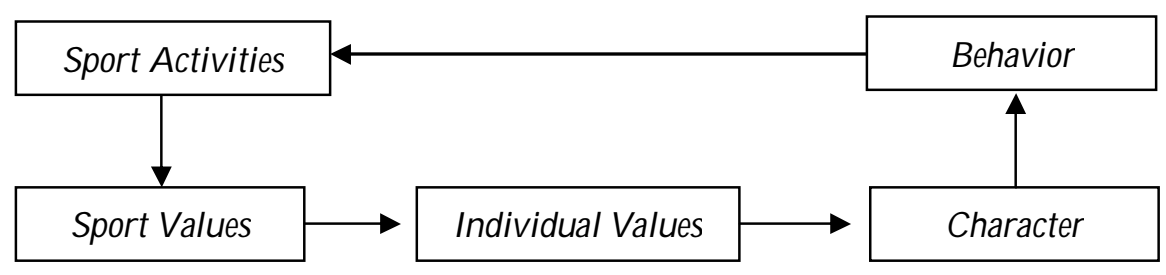

\section{Gambar 1. Model Konseptual Hubungan Olahraga-Nilai-Karakter (Sumber: Mutohir, 2004:30)}

Dalam Gambar 1 ditunjukkan dengan jelas bagaimana aktivitas olahraga yang sarat dengan nilai-nilai memengaruhi sistem nilai yang dimiliki individu. Sistem nilai yang dimiliki individu memengaruhi karakter, dan karakter selanjut-nya memengaruhi perilaku. Meskipun wujudnya sangat sederhana, dari gambar tersebut paling tidak dapat dijelaskan mengapa olahraga menjadi sesuatu yang penting dalam memengaruhi terbentuknya nilai dan karakter.

Nilai-nilai olahraga yang telah dipaparkan di atas merupakan sesuatu yang tidak asing lagi bagi semua orang dan dengan mudah orang dapat menjumpainya dalam kehidupan seharihari. Hal ini menunjukkan bahwa sejatinya olahraga mengandung nilai-nilai yang sangat esensial bagi kehidupan dan kemanusiaan. Ketika orang bermain sepak bola, misalnya, dia bukan hanya sekedar menendang dan menggiring bola, melainkan juga mem-bangun kerja sama, kepercayaan, dan respek pada orang lain. Terlalu sulit bagi seorang pemain dapat memasukkan bola ke gawang lawan tanpa ada kerja sama dengan teman satu timnya. Kerja sama akan terjalin, jika di antara pemain ada kepercayaan. Di dalam permainan sepak bola, seorang pemain juga dituntut untuk menghormati lawan, misalnya ketika lawan mengalami cedera atau bahkan memenangkan pertandingan.

Kendatipun nilai-nilai tersebut demikian menonjol dalam olahraga, dalam praktiknya masih jauh dari harapan. Kepentingan sesaat, seperti kemenangan dan harga diri lebih dikedepankan daripada nilai-nilai kemanusiaan. Hal ini tentu jauh dari yang dicita-citakan oleh Baron Pierre de Coubertin, karena olahraga sudah mengalami distorsi dan pendangkalan nilai-nilai. Olahraga sudah bukan lagi merupakan ekspresi homo ludens, melainkan telah menjadi objek homo economicus. Dalam olahraga, orang hanya berpikir menang atau kalah dan hadiah yang pada gilirannya dapat membuat orang mengabaikan sportivitas yang merupakan spirit dasar olahraga. Orang tidak malu lagi dan secara terang-terangan melobi wasit untuk memenangkan pertandingan atau sebaliknya mengintimidasi.

Beberapahasil penelitian menunjukkan adanya pengaruh aktivitas olahraga 
terhadap dimensi kepribadian, seperti konsep diri, stress, penyimpangan perilaku, dan integrasi sosial. Hasil studi Biddle, Sallis, dan Cavill (1998) menunjukkan bahwa remaja yang aktif dalam olahraga penyimpangan perilakunya lebih kecil jika dibandingkan remaja yang tidakberpartisipasi dalam olahraga. Hasil penelitian lainnya yang dilakukan oleh Brinkhoff (1998) menunjukkan bahwa remaja yang terlibat dalam aktivitas fisik lebih memiliki ketahanan dan mampu mengatasi stressor dari lingkungannya. Hasil penelitian Brettscneider (1999) menunjukkan bahwa remaja pada umumnya membutuhkan dukungan sosial, tidak saja dari kelompoknya, melainkan juga dari kelompok dan institusi lainnya. Hasil penelitian Biddle, Sallis, dan Cavill pada tahun 1998 (Mutohir, 2004:31-32) tentang konsep diri menyatakan bahwa remaja yang terlibat aktif dalam kegiatan olahraga menunjukkan tingkat kepercayaan diri (self-confidence) lebih tinggi daripada remaja yang tidak aktif terlibat dalam kegiatan olahraga.

\section{IMPLEMENTASI A K T U A L I S A S I NILAI-NILAI OLAHRAGA}

Setelah nilai-nilai olahraga sudah teraktualisasi langkah selanjutnya - dan ini yang penting - adalah mengimplementasikan nilai-nilai tersebut dalam kehidupan sehari-hari. Terkait dengan implementasi nilai, Maksum (2009:32) menawarkan dua model. Pertama, membentuk kebiasaan rutin yang bermuatan nilai-nilai olahraga, misalnya berjabat tangan dengan lawan bermain, sebelum dan sesudah bertanding, menghormati keputusan wasit walau seberat apa pun itu, peduli pada teman yang ingin mempelajari keterampilan dengan menyediakan diri sebagai mentor, dan bermain dengan berpegang pada peraturan yang ada.

Kedua, memberikan reward bagi siapa pun yang menampilkan perilaku bernilai olahraga. Menanamkan dan melaksanakan nilai-nilai olahraga tidak semudah mengajarkan keterampilan olahraga, seperti: menggiring, menendang, mengoper bola. Dibutuhkan waktu yang lama dan konsistensi yang tinggi untuk dapat meng-hayati dan mengimplementasikan nilai-nilai olahraga dalam kehidupan. Reward diberikan kepada mereka yang telah menunjukkan perilaku yang mencerminkan aktualisasi nilainilai olahraga. Penghargaan dapat diberikan dalam bentuk yang bervariasi, seperti: sertifikat, stiker, peran sebagai kapten tim, atau pujian.

Menurut Hidayatullah (2007:111), peran seorang pemimpin dalam penerapan nilai-nilai tersebut sangat penting karena harus diingat bahwa negeri ini masih menganut paham paternalistik yang sangat kuat. Oleh sebab itu, pendekatan yang paling tepat untuk penerapannya adalah melalui keteladanan dari para pemimpin, seperti: orang tua, guru, pemuka masyarakat, dan kepala pemerintahan dari tingkat yang terendah sampai yang tertinggi. Para pemimpin harus memberikan teladan yang baik, apa yang diucapkan harus berbanding lurus dengan apa yang dilakukan, baik di rumah, di sekolah, di masyarakat, maupun di pemerintahan. Jangan menuntut orang lain datang tepat waktu, sedangkan dirinya sendiri datang terlambat dan masih banyak lagi contoh 
yang dapat dijajar panjang di sini. Dimulai dari diri sendiri untuk memberikan contoh yang baik kepada orang lain, terutama para pemimpin sebagai panutan bagi yang dipimpinnya. Para pemimpin jangan hanya suka mengobral janji-janji tanpa pernah ditepati sehingga menimbulkan sakit hati.

\section{PENUTUP}

Ada nilai-nilai luhur yang terkandung dalam olahraga yang sejatinya juga merupakan nilai-nilai yang ada dalam kehidupan sehari-hari. Nilai-nilai tersebut betapa pun baik dan mulianya tidak akan mempunyai makna apa pun jika tidak diaktualisasikan dan diimplementasikan dalam kehidupan nyata. Oleh sebab itu, yang penting adalah kemauan dari setiap individu untuk memulai hidup dengan baik yang dilandasi oleh nilai-nilai keutamaan dan didukung oleh keteladan dari para pemimpin.

Hal ini sungguh bukan pekerjaan yang mudah, namun dengan adanya komitmen (political will dan political action) dari semua pihak, tidak ada barang yang tidak mungkin di dunia ini. Dengan didukung oleh semua pihak dan disertai dengan visi dan misi yang sama, mudah-mudahan tekad untuk menjadikan olahraga sebagai instrumen untuk membangun nilai dan karakter bangsa dapat menjadi kenyataan.

\section{UCAPAN TERIMA KASIH}

Pada kesempatan ini, penulis mengucapkan banyak terima kasih kepada Redaktur dan segenap pengurus Jurnal Cakrawala Pendidikan yang telah mem- berikan mimbar bagi komunikasi ilmiah ini.

\section{DAFTAR PUSTAKA}

Biro Humas dan Hukum. 2007. UndangUndang Republik Indonesia Nomor 3 Tahun 2005 tentang Sistem Keolahragaan Nasional. Jakarta: Biro Humas dan Hukum Kementerian Negara Pemuda dan Olahraga Republik Indonesia.

Capra, Fritjof. 1998. Titik balik peradaban: Sains, masyarakat, dan kebangkitan kebudayaan. (Terjemahan. M. Thoyibi). Yogyakarta: Yayasan Bentang Budaya.

Coakley, J.J. 1978. Sport in Society. Saint Louis: The CV Mosby Company.

Hidayatullah, M. Furqon. 2007. Mengantar Calon Pendidik Berkarakter di Masa Depan. Surakarta: Sebelas Maret University Press.

ICSPE. 1972. Deklarasi olahraga. (Terjemahan). Jakarta: Depdikbud, Direktorat Jenderal Olahraga dan Pemuda.

Kretchmar, R. Scott. 2005. Practical Philosophy of Sport and Physical Activity. $2^{\text {nd }}$ ed. Champaign, IL: Human Kinetics.

Maksum, Ali. 2009. "Konstruksi Nilai melalui Pendidikan Olahraga." Cakrawala Pendidikan. (Th. XXVIII, No. 1). hlm. 25-34. 
Malim, Tony. 1997. Social Psychology. $2^{\text {nd }}$ ed. London: Macmillan Press Ltd.

Mutohir, Toho Cholik. 2004. Olahraga dan pembangunan. Jakarta: Proyek Pengembangan dan Keserasian Kebijakan Olahraga, Direktorat Jenderal Olah-raga, Departemen Pendidikan Nasional.

Sudrajad, Akhmad. 2010. Tentang Pendidikan Karakter. http://akhmadsudrajad.wordpress.com/2010/08/20/pendidikan-karakterdi-smp/.
Suyanto. 2010. Urgensi Pendidikan Karakter. http://waskitamandiribk.word-press.com/2010/06/02/urgensipendidikan-karakter/.

Wilkerson, M., \& Dodder, B.A. 1979. "What Sport Does for People." Journal of Physical Education, Recreation and Dance. $(50,2)$. hlm. 50-51.

Zohar, D., \& Marshall, I. 2000. Spiritual Intelligence the Ultimate Intelligence. London: Bloomsbury Publishing Plc. 